\title{
Will the water resources of Israel, Palestine and Jordan remain sufficient to permit economic and social development for the foreseeable future?
}

Dr. Jonathan Chenoweth, Centre for Environmental Strategy, University of Surrey, Guildford, Surrey, GU2 7XH, UK. Email: j.chenoweth@surrey.ac.uk

\begin{abstract}
Scenario analysis suggests that by 2050 the population of Israel, the West Bank and Gaza Strip, and Jordan will have grown from 17.2 million to between 21.1 and 38.5 million people. These population scenarios are compared to a range of water resource scenarios that consider the effect of climate change, a possible redistribution of the region's shared water resources as a result of a peace agreement, or the status quo. This scenario analysis shows that under all possible population-water scenarios combinations considered, the water resources of Jordan and Israel remain above the minimum threshold required for social and economic development. In the case of the West Bank, water resources may also remain sufficient for all population and climatic scenarios if the West Bank gains a greater portion of the shared water resources. In the Gaza Strip, however, desalination or water imports are required.
\end{abstract}

Keywords: water resources, scenario analysis, Israel, Palestine, West Bank, Gaza, Jordan. 


\section{Introduction}

Israel, the West Bank and Gaza Strip are located between the Jordan River and the Mediterranean Sea, while the Hashemite Kingdom of Jordan is located immediately to the east of the Jordan River. The West Bank and Gaza Strip (hereafter collectively referred to as Palestine), and Israel are extremely densely settled by global standards, having a higher population density than most European countries, and in the case of Palestine, average population density significantly exceeds that of all European Union states except Malta (Central Intelligence Agency 2003). Because approximately half the land area of Israel and Palestine is arid and thus sparsely inhabited, effective population densities in non-arid areas are much higher than the average figures suggest. In Jordan the population is heavily concentrated in the Amman area while the east and south of the country are arid and sparsely settled.

Israel, Palestine and Jordan suffer from severe water scarcity, having very low water resources availability compared to the global average (Food and Agriculture Organization 2004), with this water scarcity directly impacting upon daily life and economic activity for much of the population of Palestine and Jordan. Continuing rapid population growth in the region raises the question of whether the basic water needs of the population can be met for the foreseeable future.

This paper reviews what are basic water needs - the minimum water requirement of a country in order to permit social and economic development. This minimum water 
requirement is then compared with feasible population scenarios of Israel, Palestine and Jordan for the year 2050 and feasibly water resources scenarios in order to ascertain whether the water resources should be sufficient to meet basic these social and economic needs.

\section{Minimum water requirements for social and economic development}

A range of estimates of per capita water requirements have been developed, ranging from 20 litre per capita per day (l/c/d) through to 4,654 l/c/d (1,700 m³/c/y). The WHO and UNICEF, for example, in their global assessment of water supply adopted the figure of $20 \mathrm{l} / \mathrm{c} / \mathrm{d}$ for domestic hygiene purposes as the basic minimum acceptable amount of water required per person (World Health Organisation and United Nations Children's Fund 2000). This figure is not so much a recommendation of the minimum amount of water a person requires but, rather, an observation of the amount of water a person is actually likely to use when the water source is located remote from their dwelling (but within a distance of less than a kilometre) and thus must be carried there. Howard and Batram (2003) argue that $20 \mathrm{l} / \mathrm{c} / \mathrm{d}$ will provide only basic access and will not permit all water requirements for hygiene to be met. They argue that $50 \mathrm{l} / \mathrm{c} / \mathrm{d}$ will allow most requirements to be met but that $100 \mathrm{l} / \mathrm{c} / \mathrm{d}$, which they term optimum access, will allow all domestic requirements to be met. 
Estimates higher than 100 l/c/d consider economic uses of water. Shuval (1992) suggests that $274 \mathrm{l} / \mathrm{c} / \mathrm{d}\left(100 \mathrm{~m}^{3} / \mathrm{c} / \mathrm{y}\right)$ is required by a country to meet non-agricultural water needs, with a further $68 \mathrm{l} / \mathrm{c} / \mathrm{d}\left(25 \mathrm{~m}^{3} / \mathrm{c} / \mathrm{y}\right)$ needed for essential fresh food production. Falkenmark (1986) argues that at least 1,369 l/c/d (500 m³/c/y) is required by a modern society living in semi-arid conditions, with 80 percent of this water being required for irrigation. Both Shuval and Falkenmark's estimates appear to be based upon Israel's water consumption patterns at the time that each estimate was made. Falkenmark provides higher estimates of the thresholds for water scarcity $\left(2,738 \mathrm{l} / \mathrm{c} / \mathrm{d}\right.$ or $\left.1,000 \mathrm{~m}^{3} / \mathrm{c} / \mathrm{y}\right)$ and water stress $(4,564$ l/c/d or $1,700 \mathrm{~m}^{3} / \mathrm{c} / \mathrm{y}$ ), with this higher estimate being adopted by the World Water Assessment Programme (2003) as what it describes as the minimum amount of drinking water required for an active and healthy human life.

Chenoweth (2008) argues that none of the above estimates of water requirements are appropriate for assessing the amount of water required by a country to permit social and economic development. The lower estimates only consider domestic water requirements and thus don't consider the water required by a country to run its economy and meet the economic needs of its people, while the higher estimates assume that food selfsufficiency is required, with this being achieved through irrigated agriculture in semi-arid conditions. As Allan (2001) demonstrates, countries can adapt to reduced water availability by meeting food needs through increased food imports which he terms “virtual water”, with many Middle Eastern countries depending extensively on virtual water. Countries trade their way to food self-sufficiency in the same way that cities have 
always met their food requirements primarily through trade rather than local production. FAO (2006) data shows that even the least developed countries of the world now participate to varying degrees in the global food markets, thus clearly breaking the water resource - food security nexus. While having sufficient water for food production is critical at the global level, within individual countries, it is water for domestic needs and for maintaining a non-agricultural economy that is vital as most human activities require the use of some amount of water (Chenoweth 2008).

Chenoweth (2008) suggests that there are two possible methods for calculating how much water a country requires for meeting domestic needs and the needs of a non-agricultural economy, so that it provide its people with a high quality of life. One approach is to examine water efficient countries to see if there is a minimum threshold of water consumption exhibited by countries that have achieved a high level of social and economic development. A second approach is to examine the water intensity of different economic sectors to estimate hypothetically the minimum water requirements overall for running a water efficient developed economy. Using these two approaches Chenoweth (2008) estimates that $120 \mathrm{l} / \mathrm{c} / \mathrm{d}$ are required for domestic water needs and for sustaining a water efficient economy that is capable of providing a high quality of life, with $35 \mathrm{l} / \mathrm{c} / \mathrm{d}$ being required for economic activities and 85 l/c/d being required for domestic uses. Allowing for distribution system loses of approximately ten percent increases this minimum to $135 \mathrm{l} / \mathrm{c} / \mathrm{d}$, or approximately $50 \mathrm{~m}$ /c/y (Chenoweth 2008). This estimate does not directly allow for any water for agricultural or landscape uses, such as small-scale fresh food production, gardens, parks or street vegetation. One estimate of such water 
needs, by Shuval (1992), suggested that $68 \mathrm{l} / \mathrm{c} / \mathrm{d}(25 \mathrm{~m}$ / $/ \mathrm{c} / \mathrm{y})$ was required for such uses. This volume of water, however, is able to be met from recycled wastewater since it is less than the amount of water required to satisfy non-agricultural water needs. Indeed, Israel already recycles the majority of its wastewater for agricultural uses, with such recycling reducing the need to scale back irrigated agriculture. The figure of $135 \mathrm{l} / \mathrm{c} / \mathrm{d}$ that will be used to evaluate viability of the population and water resource scenarios developed for 2050 for Israel, Palestine and Jordan.

\section{The water resources of Israel, Palestine and Jordan}

The water resources of Israel, Palestine and Jordan are a mixture of surface water and groundwater sources. The Jordan River is the major surface water resource, with Israel, Palestine and Jordan all being riparians and thus being linked hydrologically. Water quality in the upper Jordan is good, with salinity in Lake Tiberius, the major natural reservoir of the Jordan River system, being around 250 mg/l (Israeli Central Bureau of Statistics 2008). The lower Jordan downstream of Lake Tiberius is poor quality due to the diversion of saline springs naturally flowing into Lake Tiberius into the downstream river together with irrigation effluent; its waters at present are of little human use. The Yarmouk and Zarqa rivers are the major tributaries of the Jordan River, with the Yarmouk forming part of the border between Jordan and Israel, and Jordan and Syria. The Zarqa River flows into the Jordan River from Jordanian territory. 
Major groundwater sources include the Mountain and Coastal aquifers in Israel and Palestine, the Western Galilee Aquifer in Israel, and a number of groundwater basins in Jordan that are of variable water quality (U.S. Geological Survey 1998). The Mountain Aquifer is a limestone-karst aquifer which can be divided into three sub-basins. The Western Mountain aquifer and North-Eastern Mountain aquifer are located in the West Bank and Israel and thus are shared water resources, while the Eastern Mountain aquifer is located entirely within the West Bank. The Mountain Aquifer is the highest quality water source of the region, with salinity averaging $137 \mathrm{mg} / \mathrm{l}$ (Israeli Central Bureau of Statistics 2008).

The Coastal Aquifer underlies the coastal plain of Israel and the Gaza Strip. It has limited lateral flow westward towards the Mediterranean. The average salinity of the Israeli portion of the Coastal Aquifer is $198 \mathrm{mg} / \mathrm{l}$ (Israeli Central Bureau of Statistics 2008), and is increasing at a rate of $2.4 \mathrm{mg} / \mathrm{l}$ per year (Israeli Ministry of Environmental Protection 2005). In the Gaza Strip the Coastal Aquifer is suffering much more serious deterioration in water quality due to the exploitation rate of the aquifer being more than double the natural rate of replenishment, leading to significant saline intrusion of sea water from the west and naturally saline groundwater flowing from Israel in the east into the hydrological depression created by over-pumping (Weinthal et al. 2005). As a result, salinity in much of the Gaza Strip exceeds $600 \mathrm{mg} / \mathrm{l}$ and in several parts it exceeds 1000 mg/l, with less than 10 percent of total water exploited meeting the World Health Organisation's drinking water standard of less than $250 \mathrm{mg} / \mathrm{l}$ (Weinthal et al. 2005). Without significant changes to the exploitation of the Coastal Aquifer in the Gaza Strip, it 
will soon completely cease to be a useful or appropriate source of drinking water. However, the relative ease with which it is possible to dig a well and extract water from the Coastal Aquifer of the Gaza Strip together with the weak institutional structures in place to manage the resource (Trottier 1999), mean that it is unlikely that there will be a significant change to the rate exploitation in the near future.

According to Israeli sources, the renewable naturally available water resources of Israel and Palestine are 1853 million cubic metres $(\mathrm{mcm})$ per year (Israeli Ministry of Environmental Protection 2005). Palestinian sources suggest a somewhat higher total resource base of 2,634 mcm (Palestinian Academic Society for the Study of International Affairs 2007). Given that available water resources in the region are essentially fully exploited, water usage figures go some way to resolving the discrepancy. Between 2004 and 2006, water production (excluding treated wastewater) averaged $1723 \mathrm{mcm}$ per year in Israel (Israeli Central Bureau of Statistics 2008). In 2007, water production in Palestine totalled approximately $113 \mathrm{mcm}$, excluding water produced from the heavily degraded Coastal Aquifer in Gaza (Palestinian Central Bureau of Statistics 2008). Thus, it would appear that slightly more than 1800 mcm per year of renewable water resources are available in Israel and Palestine at present. The renewable water resources of Jordan, excluding the water Israel provides to Jordan under the terms of their peace treaty, are estimated to be 880 mcm (Jordanian Ministry of Water and Irrigation and Cooperation 2004). Tables 2 and 3 outline the major sources of water in Israel, Palestine and Jordan. Figure 1 shows the groundwater of the region and the Jordan River system. 


\section{Development of water allocations scenarios for Israel, Palestine and Jordan for 2050}

Some of the water resources of Israel, Palestine and Jordan, such as the Eastern Mountain Aquifer and the Western Galilee Aquifer, lie wholly within the territory of a single nation and therefore are not subject to international water resources law. Under international law, countries are expected to co-operate for the equitable use of their shared water resources, both surface waters and ground waters (International Law Commission 1999). Under international law, Palestine has riparian rights to a portion of the Jordan River's water resources just as Israel and Jordan already exploit the waters of its river basin (along with Syria and Lebanon upstream in its tributaries).

The Western Mountain Aquifer and the North-Eastern Mountain Aquifer are also shared water resources whose management is complicated by geography - the majority of the recharge areas of these aquifers lie in the West Bank but the majority of the natural discharge areas of these aquifers lie within Israeli territory, hence Israel was able to exploit these aquifers even before its occupation of the West Bank allowed it control extraction of the whole aquifer (Trottier 1999). The Coastal Aquifer is also a shared aquifer with both Israel and Palestine exploiting this aquifer, however, the amount of freshwater that would naturally flow from the Israeli to Palestinian portions of the aquifer is uncertain given the limited lateral movement within the Coastal Aquifer. Indeed, as Weinthal et al (2005) suggest somewhat controversially, based on isotopic data of the 
sources of salinity in the Gazan Coastal Aquifer, that the Israeli pumping of 6 to $10 \mathrm{mcm}$ of semi-saline groundwater annually from the Israeli portion of the Coastal Aquifer near the Gaza Strip may be helping to prevent the flow of naturally saline groundwater from Israel into the Gaza Strip and thus slowing aquifer deterioration. It is difficult to argue under international law that Palestine should gain a larger share of the Coastal Aquifer than it would gain under the natural conditions of no pumping from the aquifer in Israel.

While the Mountain Aquifer is a renewable resource of approximately $713 \mathrm{mcm}$, Palestinian exploitation is only around $113 \mathrm{mcm}$, with Israel taking most of the rest. Palestine gains no benefit from the Jordan River's waters despite having riparian rights to a portion of the flow of this river. Thus, of the shared water resources of Israel and Palestine, namely the Mountain Aquifer and the Israeli controlled portion of the Jordan River system (but excluding the Coastal Aquifer due to the limited lateral flow) which total approximately $1370 \mathrm{mcm}$, Palestine currently accesses less than ten percent directly. Palestine currently purchases approximately $49 \mathrm{mcm}$ from the Israeli water system (Palestinian Central Bureau of Statistics 2008) but even this amount boosts the Palestinian portion of shared water resources to less than 12 percent.

Unfortunately international law does not specify exactly how to determine an equitable allocation of a shared water resource, only declaring that all relevant factors and circumstances must be considered, including hydrological factors, socio-economic needs, extent of dependence of the population of each state on the water resource, existing and potential uses of the water, and the availability of alternative sources (International Law 
Commission 1999). Table 3 outlines the approximate current division of both shared and internal water resources of Israel, Palestine and Jordan. The total renewable water resources for each nation given in this table will be used in the scenario analysis as water resource scenario 1, namely the status quo for water resources.

While the per capita water resources of Israel, Palestine and Jordan as three separate nations could not be expected to be equal given their different hydrological characteristics, it is difficult to argue that the division of the shared water resources between Israel and Palestine at present is equitable given that Israel currently takes the lion's share of the Mountain Aquifer, an aquifer which predominantly underlies the West Bank and is the only water source currently available there, while at the same time Israel also uses a significant portion of the Jordan River's flow as well as internal Israeli water sources such as the Coastal Aquifer, all of which are not accessible as present to the Palestinians. However, equity is seldom clear cut and what is judged to be equitable is inherently a political judgment influenced by the history of the situation as well as perceptions about what the future may bring. Thus, sharing of water resources will need to form part of any political discussions leading towards a settlement of the IsraeliPalestinian conflict.

One hypothetical division of the shared water resources of Israel and Palestine could be to split Israel's current share of the Jordan River basin's waters and the Mountain Aquifer's water equally. Assuming that there were no further water transfers or sales from Israel to Palestine and water share of the Jordan River with Jordan and the other 
riparian nations of the Jordan River basin did not change, this would leave Israel with a total of $1117 \mathrm{mcm}$ and the West Bank with $686 \mathrm{mcm}$ per year. Such a split would reduce Israel's water resources to $430 \mathrm{l} / \mathrm{c} / \mathrm{d}$ while giving Palestine as a whole $481 \mathrm{l} / \mathrm{c} / \mathrm{d}$ and the West Bank $780 \mathrm{l} / \mathrm{c} / \mathrm{d}$. Given likely population growth, the land locked nature of the West Bank and thus its inability to desalinate sea water directly ${ }^{\mathrm{i}}$, as well as the relative importance of agriculture to the Palestinian economy, such a division of water resources could be argued to be equitable. This water resources division will be used in the scenario analysis as water resources scenario 2 - reallocated water resources - as it provides some indication of how water resources might be allocated if a comprehensive peace agreement or water sharing agreement is reached between Israel and Palestine.

When considering water resources from a long-term perspective it is useful to consider the likely effects of climate change. There is a huge uncertainty with climate models in terms of their ability to translate a predicted atmospheric concentration of greenhouse gases to specific measurable hydrological effect in a given region, and of course the extent that greenhouse gases will increase is itself also uncertain. Alpert et al (2006) suggest that modest precipitation decreases are likely in the eastern Mediterranean region of Israel, Palestine and Jordan, and depending upon the extent of climate change, this decrease will range between zero and 30 percent. Hertig and Jacobeit (2008), however, suggest that precipitation will decrease in the eastern Mediterranean region by the latter

\footnotetext{
${ }^{\mathrm{i}}$ Desalinated water could be supplied to the West Bank from a desalination plant located on the Mediterranean coast, either in the Gaza Strip or Israel, however, either option would give Israel some control over the water as the supply pipes would cross its territory thus from the Palestinian perspective and the long history of conflict between Israel and Palestine, this is unlikely to be a politically desirable option. Furthermore, with significant energy required to desalinate the sea water and then to pump it up hill to the West Bank, desalinated water would be relatively expensive compared to the water naturally available in the Mountain Aquifer occurring under the West Bank.
} 
part of twenty-first century by as much as 50 percent compared to the now. On top of any precipitation changes, higher temperatures are likely to result in at least a slight reduction in runoff and infiltration, and thus decreased availability of both surface and groundwater. For the scenario analysis it would be reasonable to consider a water scenario where resources are significantly reduced due to climate change, even if the magnitude of this reduction is very uncertain. Water resources scenario 3 will therefore assume that the reallocated water resources of scenario 2 will be reduced by one-third by 2050. Table 4 outlines the three water resource scenarios.

\section{Population scenarios for Israel, Palestine and Jordan for 2050}

Within its internationally recognised borders, Israel has an area of 20,770 sq km (Central Intelligence Agency 2008). Palestine (West Bank and Gaza Strip) has an area of 6,220, while Jordan has an area of 92,300 sq km. The current population of Israel is 7.1 million, while Palestine has a population of 3.9 million, split with 1.5 million in the Gaza Strip and 2.4 million in the West Bank. Jordan has a population of 6.2 million (Central Intelligence Agency 2008). Population growth throughout the region is high, ranging from 1.7 percent in Israel, 2.3 percent in Jordan, and 2.7 percent in Palestine. Due to this population growth alone, the total population of the region will increase significantly in the coming decades. 
According to the medium variant population estimates of the United Nations Population Division, in 2050 the population of Israel will be 10.5 million, while in Palestine it will be 10.3 million and Jordan 10.1 million (United Nations Population Division 2006). Thus, according to the best estimate of the United Nations, the population of the region will total approximately 30.9 million, assuming immigration and emigration patterns are in line with previous trends and a decline in fertility rates occurs similarly to that experienced elsewhere in the world. Under the high variant population estimate of the UN, the total population of the region reaches 35.9 million, while under the low variant estimate, it reaches 26.4 million.

These population projections may be significantly effected by population movements, particularly the movement of Palestinian refugees. In 2008 it was estimated that there were 4.6 million Palestinian refugees registered with the United Nations living in Jordan, Syria, Lebanon and Palestine (United Nations Relief and Works Agency for Palestine Refugees in the Near East 2004). If those Palestinian refugees not registered with the UN are also considered, estimates of the displaced Palestinian population range as high as seven million people (BADILL 2008). Of the 4.6 million registered with the UN, 1.8 million currently live in Palestine and thus are included in the population estimates and projections for Palestine. Another 1.9 million currently live in Jordan, where they have citizenship and are mostly well integrated into Jordanian society. These people are thus also included in the population estimates and projections for Jordan. The nearly 900,000 Palestinian refugees currently living in Syria and Lebanon, however, currently lack citizenship and for many people living conditions are extremely difficult. It is therefore 
possible that a very significant proportion of these people would choose to relocate to Palestine or Israel if given the opportunity to do so as a result of a peace settlement between Israel and its neighbours.

Immigration to Israel from Jewish communities elsewhere has played a major role in increasing Israel's population since 1948 as Israel has maintained a policy of unrestricted Jewish immigration. Between 1948 and 2007 approximately three million people immigrated to Israel, one million of whom immigrated between 1990 and 2000, the most recent major wave of immigration (Israeli Central Bureau of Statistics 2008). Since 2000 immigration to Israel has significantly slowed, with just 18,131 people immigrating to Israel in 2007. It is probable that significant immigration to Israel will continue in the future although accurately quantifying this immigration is impossible. However, allowance for immigration based on past trends is already incorporated in the United Nations Population Division estimates for 2050, thus Israeli immigration is already incorporated into the United Nations projections.

One further factor that will determine the populations of the region will of course be the nature of any political settlements which may occur between Israel and its neighbours. While a peace treaty has been signed between Israel and Jordan, and between Israel and Egypt, agreements are lacking with Israel's other neighbours, and critically of course, with the Palestinians. A number of political outcomes are possible as a result of such an agreement between Israel and the Palestinians. One option would be that the West Bank and Gaza Strip together become the sovereign state of Palestine, with borders 
approximately matching the pre-1967 armistice lines separating Israel from these two territories. This outcome appears to be where, more or less, the Oslo Peace Process of the 1990s was leading prior to the collapse of the process in 2000. It has been the stated aim of some key Palestinian groups and many international players involved in negotiations. Another political outcome could be that the West Bank and Gaza each become sovereign states. While not the officially declared aim of any political group at present, with Gaza and the Palestinian controlled parts of the West Bank currently under the rule of different Palestinian factions, such an outcome could conceivably eventuate.

Further political outcomes include the formation of a bi-national state, either an IsraeliPalestinian bi-national state, or a Palestinian-Jordanian bi-national state. A PalestinianJordanian bi-national state would nearly be a return to the situation which existed prior to 1967 when Jordan ruled the West Bank except that it might also include the Gaza Strip and thus provide the new state with a Mediterranean sea port. An Israeli-Palestinian binational state could occur as a result of political agreement that resulted in full civil and political rights for both national groups living in Israel and Palestine. Alternatively, it could also occur on a de facto basis as a continuation of Israel's military occupation of Palestine, with one national group dominating another and the vision of a two-state solution dropped for no longer being practical.

The major factors that will determine the populations of the region in 2050 are thus the speed by which fertility rates fall, the movement of Palestinian refugees, and immigration rates. In identifying population scenarios for 2050, it is useful to determine the likely 
upper and lower bounds together with the medium population scenario that can be considered most probable if population growth expectations are achieved and there are no other major events impacting on the demography of the region.

Table 5 outlines three broad population scenarios for Israel, Palestine and Jordan, and for the other possible territorial configurations. Scenario A is based upon the low population variant of the United Nations Population Division but assumes extensive emigration from the region, so the equivalent of the 20 percent of the final population of each nation has emigrated by 2050 and that there will be no unexpected immigration to the region, either Jewish or Palestinian. Scenario B is based on the medium population variant of the UN and assumes that there will be no unexpected migration of people either into or out of the region. Scenario $\mathrm{C}$ is based on the high variant of the UN but also assumes that that entire Palestinian refugee populations of Syria and Lebanon relocate to Palestine, or to a bi-national Israeli-Palestinian state or a bi-national Palestinian-Jordanian state, and that the growth rate of this refugee population matches that of the Palestinian population in Palestine. While it is extremely unlikely that the entire Palestinian refugee populations of Syria and Lebanon would move to Palestine if given the opportunity to do so, nonreturnees from these countries might be balanced by Palestinians from elsewhere in the world taking the opportunity to relocate to Palestine. For all scenarios, the individual populations given for the West Bank and Gaza Strip in Table 5 assume that the current ratio of population in these two territories remains unchanged. 
Table 5 clearly shows that under all scenarios with the exception of scenario A for Israel and Jordan, population densities will be considerably higher than those of today. In the case of scenario C, the population density of Palestine reaches in excess of 2,300 people per square kilometre, thus raising the question of whether this is even physically achievable. However, the evidence suggests that it is fully achievable even if it is not desirable. At present the population density of the Gaza Strip as a whole is nearly 4,200 people per square kilometre, while of Gaza City itself, the population density is approximately 16,450 (Demographia 2008).

By way of comparison, the projected population density for Palestine under scenario $\mathrm{C}$ is approximately twice that of Malta today. Sixteen cities in the world have population densities exceeding 20,000 people per square kilometre, with some such as Hong Kong reaching nearly 30,000 per square kilometre. If the entire population of Palestine under scenario 3 were housed at the current population density of Gaza City, then less than 15 percent of Palestine would need to be urbanised. While it is hardly desirable to emulate the overcrowded and poor living conditions that exist in much of Gaza, it is clear that extremely high population densities can be (and are) sustained, and as Hong Kong demonstrates, the level of economic development is far more critical than the population density in determining quality of life.

If the Gaza Strip were to become a politically independent nation while maintaining its current proportion of the Palestinian population, under scenario C it would have a population of 5.5 million and a population density of around 15,000 per square kilometre. 
Thus, the population density of Gaza as a whole would approximately match the current population density of Gaza City, with the urban area presumably expanding from is current 10 to 15 percent to fill most of the territory.

\section{Are the water resources of Israel, Palestine and Jordan sufficient until 2050?}

Tables 6, 7 and 8 outline the water resources per capita for each of the water and population scenario.

For population scenario A, the per capita water resources for Israel, Jordan and both binational state configurations remain above the minimum water requirement of $135 \mathrm{l} / \mathrm{c} / \mathrm{d}$ required for social and economic development. However, in most cases water resources per capita are somewhat or considerably reduced compared to current levels. For Palestine, however, even this low population growth scenario is problematic under water scenario 1 - the continuation of current water resource division - as water resources per capita remain below the minimum water requirement. With the reallocation of water resources envisaged in scenarios 2 and 3 - with or without climate change - water resources remain adequate, either for Palestine as a whole, or for the West Bank individually. Water resources for the Gaza Strip individually are inadequate under all three water resource scenarios, suggesting that large scale desalination or water imports from Israel, the West Bank or elsewhere will be required under these scenarios and all other scenarios that consider the Gaza Strip independently to the West Bank. 
Under population scenario B, water resources per capita also remain adequate for all water scenarios for Israel, Jordan and both bi-national state configurations. For Palestine, water resources per capita remain above the minimum water requirement only under water scenario 2. If the West Bank is considered separately to the Gaza Strip, water resources under water scenarios 2 and 3 remain adequate for the West Bank, again suggesting that a greater share of water is required if minimum water requirements are to be met in the long-term. With population scenario B, under all water resource scenarios Gaza would again be dependent upon desalination or water imports.

Population scenario C is clearly the most problematic from a water resources perspective. Under all three water scenarios Israel and Jordan remain above the minimum water requirement, although only barely in the case of the climate change envisaged with water scenario 3. Both bi-national states fall below minimum water requirements under water scenario 3, while the Jordanian-Palestinian bi-national state also falls below minimum water requirements under water scenario 1 . Palestine falls below the minimum water requirements level for all three water scenarios, and even the West Bank on its own is only slightly above the threshold under water scenarios 2 and 3. Gaza again requires large scale desalination or water imports. 


\section{Discussion and conclusion}

The scenario analysis considered a range of possible outcomes in terms of the distribution of water resources of Israel, Jordan and Palestine, the effects of a major reduction in water resources availability due to climate change, and varying amounts of population growth and migration. Based on plausible assumptions, this scenario analysis suggests that at the very minimum the population of the region will increase by more than 20 percent but could increase by as much as 220 percent, while water resources could decrease by as much as a third from the present. In most scenario outcomes, therefore, it is obvious that the region faces significantly less per capita water availability compared to the present. While this will present major challenges for water resource managers, the analysis suggests that the changes will be manageable.

In the case of Israel, its per capita water resources will remain above the minimum water requirement under all scenarios. This would suggest that Israel has some flexibility in any future negotiations with the Palestinians with regards to the use of shared water resources. In Jordan per capita water resources will also remain above the minimum water requirement under all scenarios. Thus, both Jordan and Israel will not be forced to make extensive use of desalination to meet their basic water needs in the foreseeable future although both will likely choose to develop their desalination capacity as a way of avoiding politically difficult transfers of water allocations from their agricultural sectors to their urban economies. They may also choose to develop their desalination capacity in 
order to provide security against climatic variability, particularly if their naturally available per capita water resources approach the minimum water requirement.

In the case of Palestine as a whole, or if the West Bank and Gaza Strip are considered individually, per capita water resources are consistently inadequate without a greater allocation of the shared water resources and without such a reallocation of water resources or new water resources being developed, the situation is bleak. However, if a reallocation of occurs that is of a similar magnitude to that outlined in this paper, per capita water resources for the West Bank will be above the minimum water requirement for all population and climate change scenarios. For the Gaza Strip though, it is clear that water imports or desalination are required under all scenarios. The Mediterranean coast and the low-lying nature of the Gaza Strip, together with the falling cost of desalination mean that this should be possible, particularly if outside financial and technical support can be found.

Israel, Palestine and Jordan are likely for the foreseeable future to have sufficient naturally available water resources to permit social and economic development if water resources are equitably shared and are managed effectively and extremely efficiently. The only exception to this is the Gaza Strip where the basic water requirements need to be met through desalination or the importation of water from elsewhere. 


\section{References:}

Allan, T. (2001). The Middle East water question: Hydropolitics and the global economy. London, I.B.

Tauris.

Alpert, P., S. O. Krichak, M. Dayan and H. Shafir (2006). "Climatic trends over the Eastern Mediterranean: past and future projections." CLIVAR Exchanges 11(2): 12-13.

BADILL. (2008). "BADIL Resource Center for Palestinian Residency and Refugee Rights." Retrieved 29 October, 2008, from http://www.badil.org/index.html.

Central Intelligence Agency. (2003). "The World Fact Book 2003." Retrieved 20 January, 2004, from http://www.odci.gov/cia/publications/factbook/index.html.

Central Intelligence Agency. (2008). "The World Fact Book 2008." Retrieved 28 October 2008, 2008, from http://www.odci.gov/cia/publications/factbook/index.html.

Chenoweth, J. (2008). "Minimum water requirement for social and economic development." Desalination 229: 245-256.

Demographia (2008). World Urban Areas: Population and Density. Belleville, Demographia.

Falkenmark, M. (1986). "Fresh water - time for a modified approach." Ambio 15: 192-200.

Food and Agriculture Organization. (2004). "Aquastat: FAO's Information System on Water and Agriculture." Retrieved 17 June 2004, 2004, from http://www.fao.org/ag/agl/aglw/aquastat/dbase/index.stm. 
Food and Agriculture Organization. (2006). "FAOSTAT - Nutritional Data." Retrieved 13 July 2006, 2006, from http://faostat.fao.org/faostat/collections?subset=nutrition.

Hertig, E. and J. Jacobeit (2008). "Assessments of Mediterranean precipitation changes for the 21st century using statistical downscaling techniques." International Journal of Climatology 28: 1025-1045.

Howard, G. and J. Bartram (2003). Domestic Water Quantity, Service, Level and Health. Geneva, World Health Organization.

International Law Commission (1999). Convention on the Law of the Non-navigational Uses of International Watercourses, 1997. http://www.un.org/law/ilc/texts/nonnav.htm, United Nations Webserver.

Israeli Central Bureau of Statistics (2008). Statistical Abstract of Israel. Jerusalem, Central Bureau of Statistics.

Israeli Ministry of Environmental Protection. (2005). "Yield's of Israel's Water Resources." Retrieved 27 October 2008, 2008, from http://www.sviva.gov.il/bin/en.jsp?enPage=e_BlankPage\&enDisplay=view\&enDispWhat=Object\&enDisp Who=Articals^12053\&enZone=Water_Sources.

Jordanian Ministry of Water and Irrigation and G. T. Cooperation (2004). National Water Master Plan. Amman, Jordanian Ministry of Water and Irrigation.

Palestinian Academic Society for the Study of International Affairs. (2007). "Water and Environment." from http://www.passia.org/palestine_facts/pdf/pdf2006/7-Water-Environment.pdf.

Palestinian Central Bureau of Statistics. (2008). "Water Statistics in the Palestinian Territory 2007." from http://www.pcbs.gov.ps/Portals/_PCBS/Downloads/book1476.pdf. 
Shuval, H. (1992). "Approaches to Resolving the Water Conflicts Between Israel and her Neighbors - A

Regional Water-for-Peace Plan." Water International 17(3): 122-143.

Trottier, J. (1999). Hydropolitics in the West Bank and Gaza Strip. Jerusalem, Palestinian Academic Society for the Study of International Affairs.

U.S. Geological Survey (1998). Overview of Middle East Water Resources: Water Resources of Palestinian, Jordanian, and Israeli Interest, Executive Action Team, Middle East Water Data Banks Project: 44.

United Nations Population Division (2006). World Population Prospects: The 2006 Revision Population Database. New York, United Nations.

United Nations Relief and Works Agency for Palestine Refugees in the Near East. (2004). "United Nations Relief and Works Agency for Palestine Refugees in the Near East." Retrieved 29 October 2008, 2008, from http://www.un.org/unrwa/.

Weinthal, E., A. Vengosh, A. Marei, A. Gutierrez and W. Kloppmann (2005). "The Water Crisis in the Gaza Strip: Prospects for Resolution." Ground Water 43(5): 653-660.

World Health Organisation and United Nations Children's Fund (2000). Global Water Supply and Sanitation Assessment 2000 Report. Geneva, World Health Organisation / UNICEF.

World Water Assessment Programme (2003). Water for People, Water for Life: The United Nations World Water Development Report. Paris, UNESCO publishing / Berghahn Books. 



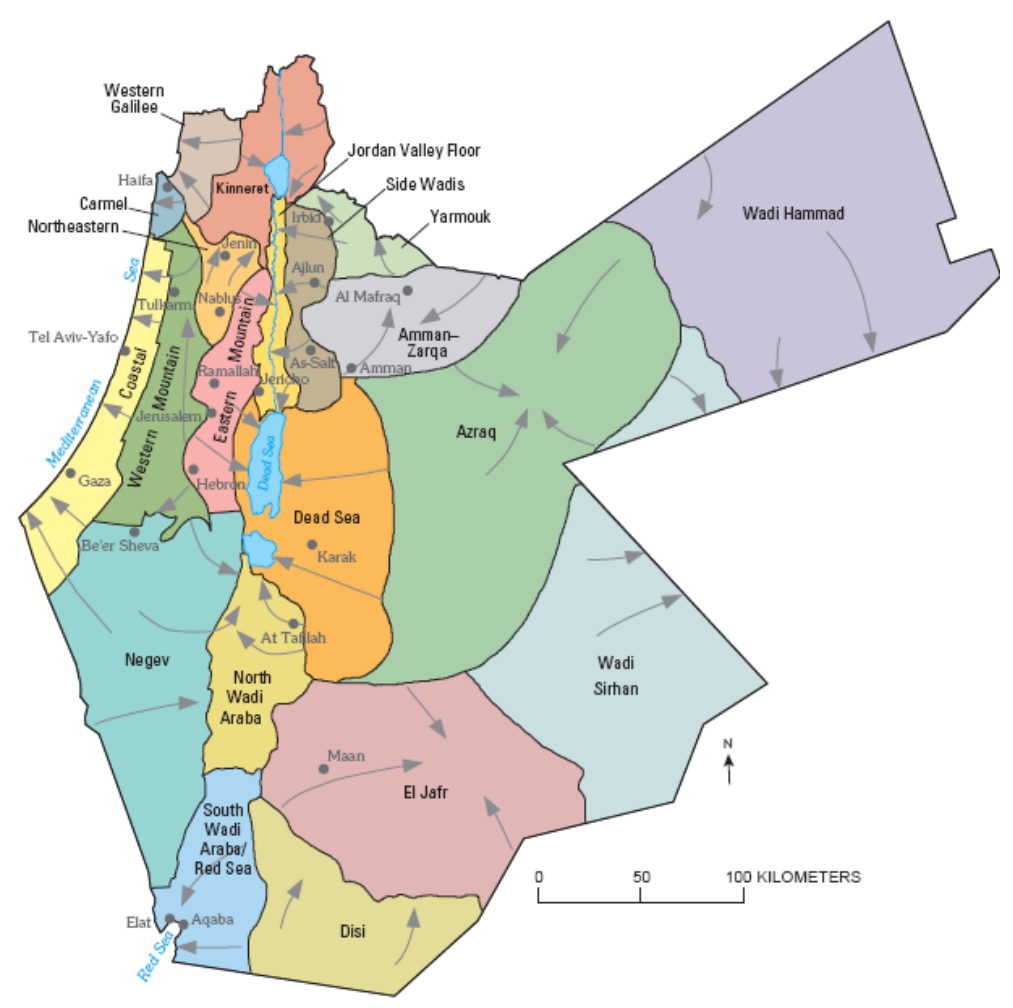

Figure 1: The groundwater basins and Jordan River system of Israel, Palestine and Jordan. (U.S. Geological Survey 1998, p11) 
Table 1: Available renewable water according to source in Israel / Palestine (Israeli Ministry of Environmental Protection 2005).

\begin{tabular}{|l|c|}
\hline Resource & $\begin{array}{l}\text { Renewable water } \\
\text { (MCM/year) }\end{array}$ \\
\hline Coastal Aquifer & 249 \\
\hline Western Mountain Aquifer & 360 \\
\hline Eastern Mountain Aquifer & 353 \\
\hline Western Galilee Aquifer & 153 \\
\hline Lake Tiberias / Jordan River & 659 \\
\hline Other sources & 79 \\
\hline Total & 1,853 \\
\hline
\end{tabular}

Table 2: Available renewable water by source in Jordan, excluding the $50 \mathrm{mcm}$ of water provided by Israel to Jordan under the Israeli-Jordanian Peace Treaty (Jordanian Ministry of Water and Irrigation and Cooperation 2004).

\begin{tabular}{|c|c|c|c|}
\hline \multicolumn{2}{|l|}{ Resource } & \multicolumn{2}{|c|}{ Renewable water (MCM / year) } \\
\hline \multirow{12}{*}{$\begin{array}{l}\text { Renewable } \\
\text { groundwater }\end{array}$} & Jordan valley & $15-20$ & \multirow{12}{*}{259} \\
\hline & Jordan side valley & $28-32$ & \\
\hline & Yarmouk & $30-35$ & \\
\hline & Amman-Zarqa & $60-70$ & \\
\hline & Azraq & $30-45$ & \\
\hline & Hammad & $12-16$ & \\
\hline & Dead Sea & $40-50$ & \\
\hline & Wadi Araba North & $5-7$ & \\
\hline & Wadi Araba South & $4-6$ & \\
\hline & Jafr & $7-10$ & \\
\hline & Sarhan & $4-6$ & \\
\hline & Southern Desert & $2-3$ & \\
\hline \multirow[t]{2}{*}{ Surface water } & $\begin{array}{l}\text { Internal Jordanian } \\
\text { surface waters } \\
\text { (median annual } \\
\text { flood flow and } \\
\text { base flow) }\end{array}$ & & 454 \\
\hline & Yarmouk River & & 167 \\
\hline Total & & & 880 \\
\hline
\end{tabular}


Table 3: The approximate current division of the water resources of Israel, Palestine and Jordan, excluding the degraded Coastal Aquifer of the Gaza Strip. Population data are from Central Intelligence Agency (2008).

\begin{tabular}{|c|c|c|c|c|}
\hline \multirow{2}{*}{$\begin{array}{l}\text { Water } \\
\text { source }\end{array}$} & \multirow{2}{*}{$\begin{array}{l}\text { Renewable } \\
\text { volume } \\
\text { (mcm) }\end{array}$} & \multicolumn{3}{|c|}{ Current division: Volume \& percentage share } \\
\hline & & Israel & Palestine & Jordan \\
\hline $\begin{array}{l}\text { Coastal } \\
\text { aquifer }\end{array}$ & 249 & $249(100 \%)$ & ii & - \\
\hline $\begin{array}{l}\text { Mountain } \\
\text { aquifer }\end{array}$ & 713 & $\begin{array}{l}600 \\
(84 \%)\end{array}$ & $\begin{array}{l}113 \\
(16 \%)\end{array}$ & - \\
\hline $\begin{array}{l}\text { Western } \\
\text { Galilee } \\
\text { Aquifer } \\
\text { (and other } \\
\text { internal } \\
\text { Israeli } \\
\text { sources) }\end{array}$ & 232 & $232(100 \%)$ & - & - \\
\hline $\begin{array}{l}\text { Internal } \\
\text { Jordanian } \\
\text { aquifers } \\
\end{array}$ & 259 & - & - & $259(100 \%)$ \\
\hline $\begin{array}{l}\text { Jordan } \\
\text { River basin }\end{array}$ & 1280 & $\begin{array}{l}659 \\
(51 \%)\end{array}$ & $0 \%$ & $621(49 \%)$ \\
\hline $\begin{array}{l}\text { Water sales } \\
\text { / transfers }\end{array}$ & & -99 & $\begin{array}{l}49 \text { (45 to West Bank; } \\
5 \text { to Gaza Strip) }\end{array}$ & 50 \\
\hline $\begin{array}{l}\text { Total } \\
\text { renewable } \\
\text { water } \\
\text { resources }\end{array}$ & 2733 & $1641(60 \%)$ & $\begin{array}{l}162 \\
(6 \%)\end{array}$ & $\begin{array}{l}930 \\
(34 \%)\end{array}$ \\
\hline $\begin{array}{l}\text { Current per } \\
\text { capita } \\
\text { water } \\
\text { resources } \\
\text { (l/c/d) }\end{array}$ & 435 & 632 & $\begin{array}{l}113 \text { (total) } \\
179 \text { (WB) } \\
9 \text { (Gaza) }^{\mathrm{iii}}\end{array}$ & 411 \\
\hline
\end{tabular}

\footnotetext{
${ }^{i i}$ Current exploitation of the Gaza portion of the Coastal Aquifer is $172.5 \mathrm{mcm}$, however, most of this water fails WHO drinking water standards, and the continuing rapid deterioration of this resource suggest that it will not be able to be used as a freshwater resource in 2050 .

iii Including the semi-saline waters from the Gazan Coastal Aquifer, the current water resource per capita for Palestine as a whole is $235 \mathrm{l} / \mathrm{c} / \mathrm{d}$, and for Gaza is $323 \mathrm{l} / \mathrm{c} / \mathrm{d}$.
} 
Table 4: Natural renewable water resources for Israel, Palestine and Jordan under each of the Water Resource Scenarios in mcm.

\begin{tabular}{|c|c|c|c|}
\hline \multirow[t]{2}{*}{ Nation } & \multicolumn{3}{|c|}{ Water resource scenario } \\
\hline & 1 & 2 & 3 \\
\hline Israel & 1641 & 1117 & 745 \\
\hline Palestine & 162 & 686 & 457 \\
\hline $\begin{array}{l}\text { West Bank } \\
\text { Gaza }\end{array}$ & 157 & 686 & 457 \\
\hline $\begin{array}{ll} & \text { Gaza } \\
\text { Jordan }\end{array}$ & 930 & 930 & 620 \\
\hline
\end{tabular}


Table 5: Population projections and resulting population densities for the different scenarios. (Current situation data: CIA World Fact Book 2008)

\begin{tabular}{|c|c|c|c|}
\hline Scenario & Geographic area & $\begin{array}{l}\text { Population } \\
\text { (millions) }\end{array}$ & $\begin{array}{l}\text { Population density } \\
\text { (persons } / \mathrm{km}^{2} \text { ) }\end{array}$ \\
\hline \multirow{3}{*}{$\begin{array}{l}\text { Current } \\
\text { situation }\end{array}$} & Israel & 7.1 & 350 \\
\hline & Palestine & 3.9 & 628 \\
\hline & Jordan & 6.2 & 67 \\
\hline \multirow{6}{*}{$\begin{array}{l}\text { Scenario A: } \\
\text { Low }\end{array}$} & Israel & 7.2 & 354 \\
\hline & Palestine & 7.1 & 1,141 \\
\hline & $\begin{array}{r}\text { West Bank } \\
\text { Gaza }\end{array}$ & $\begin{array}{l}4.4 \\
2.7\end{array}$ & $\begin{array}{r}751 \\
7,500\end{array}$ \\
\hline & Jordan & 6.8 & 74 \\
\hline & $\begin{array}{l}\text { Bi-national } \\
\text { Israeli- } \\
\text { Palestinian state }\end{array}$ & 14.3 & 539 \\
\hline & $\begin{array}{l}\text { Bi-national } \\
\text { Jordanian- } \\
\text { Palestinian state }\end{array}$ & 13.9 & 142 \\
\hline \multirow{6}{*}{$\begin{array}{l}\text { Scenario B: } \\
\text { Medium }\end{array}$} & Israel & 10.5 & 516 \\
\hline & Palestine & 10.3 & 1,656 \\
\hline & $\begin{array}{r}\text { West Bank } \\
\text { Gaza }\end{array}$ & $\frac{6.3}{4.0}$ & $\begin{array}{r}1,075 \\
11,111\end{array}$ \\
\hline & Jordan & 10.1 & 110 \\
\hline & $\begin{array}{l}\text { Bi-national } \\
\text { Israeli- } \\
\text { Palestinian state }\end{array}$ & 20.8 & 768 \\
\hline & $\begin{array}{l}\text { Bi-national } \\
\text { Jordanian- } \\
\text { Palestinian state }\end{array}$ & 20.4 & 208 \\
\hline \multirow{6}{*}{$\begin{array}{l}\text { Scenario C: } \\
\text { High }\end{array}$} & Israel & 12.2 & 600 \\
\hline & Palestine & 14.4 & 2,315 \\
\hline & $\begin{array}{r}\text { West Bank } \\
\text { Gaza }\end{array}$ & $\begin{array}{l}8.9 \\
5.5 \\
\end{array}$ & $\begin{array}{r}1,519 \\
15,278 \\
\end{array}$ \\
\hline & Jordan & 11.9 & 129 \\
\hline & $\begin{array}{l}\text { Bi-national } \\
\text { Israeli- } \\
\text { Palestinian state }\end{array}$ & 26.6 & 1,002 \\
\hline & $\begin{array}{l}\text { Bi-national } \\
\text { Jordanian- } \\
\text { Palestinian state }\end{array}$ & 26.3 & 268 \\
\hline
\end{tabular}


Table 6: Water resources per capita under the different water resource scenarios for population scenario 1 (Low population growth and significant emigration).

\begin{tabular}{|c|c|c|c|c|}
\hline \multirow[t]{2}{*}{ Nation } & \multirow[t]{2}{*}{ Population } & \multicolumn{3}{|c|}{ Water Resources per capita (l/c/d) } \\
\hline & & $\begin{array}{l}\text { Water } \\
\text { scenario1 }\end{array}$ & $\begin{array}{l}\text { Water } \\
\text { scenario2 }\end{array}$ & $\begin{array}{l}\text { Water } \\
\text { scenario3 }\end{array}$ \\
\hline Israel & 7.2 & 624 & 425 & 283 \\
\hline Palestine & 7.1 & 62 & 265 & 176 \\
\hline West Bank & 4.4 & 98 & 427 & 28 \\
\hline Gaza & 2.7 & 5 & 0 & 0 \\
\hline Jordan & 6.8 & 374 & 374 & 230 \\
\hline $\begin{array}{l}\text { Bi-national } \\
\text { Israeli- } \\
\text { Palestinian } \\
\text { state }\end{array}$ & 14.3 & 345 & 345 & 230 \\
\hline $\begin{array}{l}\text { Bi-national } \\
\text { Jordanian- } \\
\text { Palestinian } \\
\text { state }\end{array}$ & 13.9 & 215 & 318 & 212 \\
\hline
\end{tabular}

Table 7: Water resources per capita under the different water resource scenarios for population scenario 2 (Medium population growth and no significant migration changes).

\begin{tabular}{|c|c|c|c|c|}
\hline \multirow[t]{2}{*}{ Nation } & \multirow[t]{2}{*}{ Population } & \multicolumn{3}{|c|}{ Water Resources per capita (l/c/d) } \\
\hline & & $\begin{array}{l}\text { Water } \\
\text { scenario1 }\end{array}$ & $\begin{array}{l}\text { Water } \\
\text { scenario2 }\end{array}$ & $\begin{array}{l}\text { Water } \\
\text { scenario3 }\end{array}$ \\
\hline Israel & 10.5 & 428 & 291 & 194 \\
\hline Palestine & 10.3 & 43 & 182 & 121 \\
\hline West Bank & 6.3 & $\frac{68}{3}$ & 298 & 199 \\
\hline Gaza & 4.0 & 3 & 0 & 0 \\
\hline Jordan & 10.1 & 252 & 252 & 168 \\
\hline $\begin{array}{l}\text { Bi-national } \\
\text { Israeli- } \\
\text { Palestinian } \\
\text { state }\end{array}$ & 20.8 & 237 & 237 & 158 \\
\hline $\begin{array}{l}\text { Bi-national } \\
\text { Jordanian- } \\
\text { Palestinian } \\
\text { state }\end{array}$ & 20.4 & 147 & 217 & 145 \\
\hline
\end{tabular}


Table 8: Water resources per capita under the different water resource scenarios for population scenario 3 (High population growth and significant influx of Palestinian refugees).

\begin{tabular}{|c|c|c|c|c|}
\hline \multirow[t]{2}{*}{ Nation } & \multirow[t]{2}{*}{ Population } & \multicolumn{3}{|c|}{ Water Resources per capita (l/c/d) } \\
\hline & & $\begin{array}{l}\text { Water } \\
\text { scenario1 }\end{array}$ & $\begin{array}{l}\text { Water } \\
\text { scenario2 }\end{array}$ & $\begin{array}{l}\text { Water } \\
\text { scenario3 }\end{array}$ \\
\hline Israel & 12.2 & 368 & 251 & 167 \\
\hline Palestine & 14.4 & 31 & 130 & 87 \\
\hline West Bank & 8.9 & 48 & 211 & 141 \\
\hline Gaza & 5.5 & 2 & 0 & 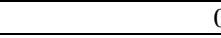 \\
\hline Jordan & 11.9 & 214 & 214 & 143 \\
\hline $\begin{array}{l}\text { Bi-national } \\
\text { Israeli- } \\
\text { Palestinian } \\
\text { state }\end{array}$ & 26.6 & 186 & 186 & 124 \\
\hline $\begin{array}{l}\text { Bi-national } \\
\text { Jordanian- } \\
\text { Palestinian } \\
\text { state }\end{array}$ & 26.3 & 114 & 168 & 112 \\
\hline
\end{tabular}

